\title{
Comparative Studies of the Optical Absorbance and Structural Properties of Ironcopper Sulphide(CuS-Fe) and Iron Lead Sulphide(PbS-Fe) Thin Films Deposited by Silar Method
}

\author{
UDEAJAH, V.N. AND ONAH, D.U \\ Department of Industrial Physics, Ebonyi State University, Abakaliki
}

\begin{abstract}
The influence of iron on lead sulphide $(\mathrm{PbS})$ and Copper Sulphide $(\mathrm{CuS})$ thin films deposited on glass substrates via successive ionic layer adsorption (SILAR) Technique using lead acetate, $\mathrm{Pb}\left(\mathrm{CH}_{3} \mathrm{COO}\right)_{2}$, Cupric Acetate $\mathrm{Cu}\left(\mathrm{CH}_{3} \mathrm{COO}\right)_{2}$, thioacetamide $\left(\mathrm{S}_{2} \mathrm{H}_{5} \mathrm{NS}\right)$, Iron (II) Chloride dehydrate $\left(\mathrm{Fe} \mathrm{Cl}_{2} \cdot 2 \mathrm{H}_{2} \mathrm{O}\right)$, ethanol and ammonia by in alkaline medium annealed between $283 \mathrm{~K}$ and $500 \mathrm{~K}$ was investigated. The structural and morphological studies were performed by X-ray diffraction (XRD) Analysis and scanning electron microscopy(SEM) respectively. The Uv-visible studies were done using spectrometer in the Technical University, Ibadan. The XRD showed films of cubic crystalline $\mathrm{PbS}$ thin films, cubic and face-centred crystalline $\mathrm{PbSFe}$ thin films, cubic $\mathrm{CuS}$ thin film, hexagonal $\mathrm{Cu}_{2} \mathrm{~S}$ thin films and cubic and hexagonal crystalline natured $\mathrm{CuSFe}$ thin films with the preferential (111),(002)(004) (311) orientations.
\end{abstract}

Keywords: Copper Sulphide thin Films: Lead Sulphide thin Films: Absorbance: structural properties

DOI: $10.7176 /$ APTA/82-04

Publication date: January $31^{\text {st }} 2020$

\section{INTRODUCTION}

It is the energy crisis in the world that gave rise to the thin film growth research as a way to cushion problems associated with it. The continuous increase in population and industrialisation in almost every country in the world, has been very responsible for the ever growing or increasing energy demand. In Nigeria, less than $40 \%$ of the country is connected to the national electric grid and less than $60 \%$ of the energy demand by this group is generated and distributed (Bala et al. 2008). The advantage of energy is facilitation of the provision of those things which are necessary for the welfare of human existence: health, heat, food, light, clothing, shelter and transport, etc. Energy availability improves the standard of living (Whitefield, 2000). Solar energy, an energy obtained from the sun, is the world's most abundant and cheapest source of energy available from Nature (Nwoke et al, 2008). It is free and automatically renewable every day. In the world over, emphasis has shifted from the use of hydro and fossil-powered electricity generation to renewable energy such as solar source through nanotechnology involving growing of thin films from the abundant transition metals, resulting in getting ones with excellent properties that will be useful in solving the problem of energy crisis (Jesuleye and Siyanbola, 2008). In the present study, lead sulphide and copper sulphide are studied to ascertain the structural and morphological properties when doped with iron. These new assumed properties will help determine their best areas of applicability. Lead sulphide $(\mathrm{PbS})$ and Copper Sulphide $\left(\mathrm{Cu}_{2} \mathrm{~S}\right)$ are groups IV-VI and I-VI compounds of semiconducting materials respectively

( Liang and Whangbo, 1993) that have drawn attention of many researchers because of its properties that have been applied widely in optoelectronic devices, photoconductors, sensors, infra-red detector devices solar cells, solar control and solar absorber coatings (chatterki et al. (2012), koao et al. (2014), Preetha et al.(2015)).

The present study describes successive ionic layer adsorption and reaction method for the synthesis and deposition of $\mathrm{PbS},(\mathrm{PbS})_{x}(\mathrm{Fe})_{1-x}, \mathrm{CuS}$ and $(\mathrm{CuS}) \times(\mathrm{Fe})_{1-x}$ ternary thin films and the influence of iron added to the halide thin films structurally and morphologically. Variety of materials such as insulators, semiconductors, metals and temperature sensitive materials like polyester can be used as a substrate since the deposition is carried out at or near to room temperature. As it is a low temperature process, it avoids oxidation and corrosion of the substrate. In spite of this SILAR having a number of advantages as compared to other methods; it does not require vacuum at any stage, doping of any element can be achieved easily, film thickness can be easily controlled by adjusting the number of deposition cycles, operating at room temperature, no restrictions on substrate material, dimensions or its surface profile etc. The prime requisite for obtaining good quality thin film is the optimization of various preparative parameters viz. concentration of precursors, nature of complexing agent, $\mathrm{pH}$ of the precursor solutions and adsorption, reaction and rinsing time durations etc.(Valenzuela, 2003)

\subsection{EXPERIMENTAL PROCEDURE:}

The layer-by-layer growth of the material is achieved by dipping the substrate alternately into separately placed cationic and anionic precursors. After every cationic and anionic immersion the substrate is rinsed in deionised water to remove the un-adsorbed ions from the surface.

The synthesis and deposition of $\mathrm{PbS}$ and $\mathrm{CuS}$ involved four steps while that of PbSFe and $\mathrm{CuSFe}$ thin films 
involved six steps. After pre-treatment of the substrates, the synthesis were done using .05M lead acetate and thioacetamide solution. Ammonia was used to control the $\mathrm{pH}$. It was done between $\mathrm{pH}$ between 8.5 and 11.5. The iron ions were got from iron(II) chloride dehydrate. The copper ions were got from cupric acetate. It was equally deposited in alkaline environment too.

For a SILAR growth of $\mathrm{PbS}$ thin film, only four steps are involved, namely:

- $\quad$ The glass substrate was first immersed in lead acetate solution for 35 minutes, where lead ions were adsorbed on the surface of the substrate.

- $\quad$ The second step involves the rinsing of the substrate for 35 seconds in deionised water to remove loose and unadsorbed lead ions from the surface.

- $\quad$ The substrate was then immersed in thioacetamide solution for 35 seconds, where the sulphur ions react with the pre-adsorbed lead ions on the substrate surface to form lead sulphide layer,

- $\quad$ Finally, the substrate was rinsed again with deionised water to remove unadsorbed and loose material from the substrate surface.

- $\quad$ A SILAR growth cycle for $\mathrm{PbS}_{\mathrm{x}} \mathrm{Fe}_{(1-\mathrm{x})}$ thin films has six.steps, namely:

- The glass substrate was first immersed in lead acetate solution for 35 seconds, where lead ions were adsorbed on the surface of the substrate.

- $\quad$ The second step involves the rinsing of the substrate for 35 seconds in deionised water to remove loose and unadsorbed lead ions from the surface.

- The substrate was then immersed in thioacetamide solution for 35 seconds, where the sulphur ions react with the pre-adsorbed lead ions on the substrate surface to form lead sulphide layer,

- $\quad$ Finally, the substrate was rinsed again with deionised water to remove unadsorbed and loose material from the substrate surface,

- $\quad$ The substrate was immersed in iron(II) Chloride dehydrate solution to adsorb iron ions on the preadsorbed lead sulphide layer,

- $\quad$ The unadsorbed iron ions were removed from the substrate by rinsing in deionised water for 35 seconds. After repeating for sufficient number of cycles( 90 cycles), $\mathrm{PbS}_{\mathrm{x}} \mathrm{Fe}_{(1-\mathrm{x})}$ composite thin films were deposited. The number of deposition cycles for $\mathrm{PbS}$ and $\mathrm{Fe}$ were adjusted to obtain various compositions of $\mathrm{PbS} \mathrm{Fe}_{(1-\mathrm{x})}$ thin films(see table 1 below)

Table 1: Deposition scheme for the growth of $\mathrm{PbS}_{\mathrm{x}} \mathrm{Fe}_{(1-\mathrm{x})}$ thin films Preparative Parameter Cationic precursors

$\begin{array}{lllc} & \mathrm{Pb}\left(\mathrm{CH}_{3} \mathrm{COO}\right)_{2} & \mathrm{FeCl}_{2.2 \mathrm{H}_{2} \mathrm{O}} & \mathrm{S}_{2} \mathrm{H}_{5} \mathrm{NS} \\ \text { Concentration(M) } & 0.05 & 0.05 & 0.05 \\ \mathrm{pH} & 11.5 & 8.5 & 11.5 \\ \text { Immersion time (seconds) } & 35 & 35 & 35 \\ \text { Rinsing time (seconds) } & 35 & 35 & 35\end{array}$

Table 2: $\mathrm{PbS}_{\mathrm{x}} \mathrm{Fe}_{(1-\mathrm{x})}$ thin films composition

\begin{tabular}{lcccc}
\hline Films & $\begin{array}{c}\text { Composition } \\
\text { parameter(x) }\end{array}$ & \multicolumn{2}{c}{$\begin{array}{c}\text { Number of SILAR cycles } \\
\mathrm{PbS}\end{array}$} & \multicolumn{2}{l}{ Thickness (nm) } \\
\hline $\mathrm{PbS}$ & 1.00 & 90 & 00 & 397 \\
$\mathrm{PbS}_{0.80} \mathrm{Fe}_{0.20}$ & 0.80 & 80 & 10 & 393 \\
$\mathrm{PbS}_{0.50} \mathrm{Fe}_{0.50}$ & 0.50 & 70 & 20 & 283 \\
$\mathrm{PbS}_{0.2} \mathrm{Fe}_{08}$ & 0.20 & 60 & 30 & 299 \\
$\mathrm{PbS}_{.10} \mathrm{Fe}_{0.9}$ & 0.10 & 45 & 45 & 230 \\
\hline
\end{tabular}

The thickness of the composite $(\mathrm{PbS})_{x}(\mathrm{Fe})_{(1-x)}$ thin film was measured by weight difference method. The density of $\mathrm{PbS}$ was taken as $4.9 \mathrm{~g} / \mathrm{cm}^{3}$ and iron as $5.2 \mathrm{~g} / \mathrm{cm}^{3}$.

The densities of the composite $(\mathrm{PbS})_{x}(\mathrm{Fe})_{(1-x)}$ thin films were estimated by considering compositional parameter ' $x$ '. The weights of the deposited films were determined by using an electronic microbalance. In the present investigation thickness of $(\mathrm{PbS})_{x}(\mathrm{Fe})_{(1-x)}$ films measured using sensitive microbalance is listed in table 2 above. The site for the research work was the crystal growth laboratory, Physics and Astronomy Department, University of Nigeria, Nsukka, Nigeria. The structural properties of the $(\mathrm{PbS})_{x}(\mathrm{Fe})_{(1-x)}$ composite thin films were studied by X-ray diffractometer with $\mathrm{CuK} \alpha$ radiation of wavelength $0.154 \mathrm{~nm}$. The surface morphological investigations were performed using scanning electron microscopy analysis and energy dispersive spectrometry (EDS) analysis at the Department of Industrial Chemistry, The Technical University, Ibadan Nigeria.

B. Copper Sulphide and Copper Sulphide Iron thin films.

The substrates were pre-treated as in the case above. For the SILAR deposition of $(\mathrm{CuS})_{(1-x)}$ thin films, $0.05 \mathrm{M}$ cupric acetate solutions were taken as cationic precursor and $0.05 \mathrm{M}$ thioacetamide as anionic precursor. The $\mathrm{pH}$ of the anionic and cationic precursors was adjusted to 12 and 8 by ammonia addition. Substrate was 
immersed in the cupric acetate solution for $35 \mathrm{~s}$ to adsorb $\mathrm{Cu}^{2+}$ ions. (a) The un-adsorbed $\mathrm{Cu}^{2+}$ ions were removed from the substrate by rinsing it in deionised water for $35 \mathrm{~s}$. (b) The substrate was then again immersed in thioacetamide solution for $35 \mathrm{~s}$, where $\mathrm{S}^{2-}$ ions reacted with $\mathrm{Cu}^{2+}$ to form a layer of $\mathrm{CuS}$. After repeating a sufficient number of cycles. It was removed and dried in an oven to avoid dust and oxidation. . For the SILAR deposition of $(\mathrm{CuS})_{(1-x)} \mathrm{Fe}(1-\mathrm{x})$ thin films, the pre-treated glass substrates were immersed into $0.05 \mathrm{M}$ cupric acetate solutions taken as cationic precursor, then rinsed in deionised water for 35 seconds before immersing into $0.05 \mathrm{M}$ thioacetamide, taken as anionic precursor for 35 seconds before rinsing in deionised water. This was repeated for several cycles before the substrate was immersed in iron(II) Chloride dehydrate solution to adsorb iron ions on the pre-adsorbed copper sulphide layer.

The unadsorbed iron ions were removed from the substrate by rinsing in deionised water for 35 seconds. It is worthy to note that the substrate was again immersed in thioactetamide solution where $\mathrm{S}^{2-}$ ions react with $\mathrm{Cu}^{2+}$ to form a layer of $\mathrm{CuS}$. After repeating a sufficient number of cycles, $(\mathrm{Fe})_{1-x}(\mathrm{CuS})_{(x)}$ composite thin films were deposited. The number of deposition cycles for $\mathrm{CuS}$ and $\mathrm{Fe}$ was adjusted to obtain various compositions of $(\mathrm{Fe})$ ${ }_{1-x}(\mathrm{CuS})_{\mathrm{x}}$.

Table 3: Deposition scheme for the growth of $\mathrm{CuS} \times \mathrm{Fe}(1-\mathrm{x})$ thin films

Preparative Parameter

Cationic precursors

\section{$\mathrm{Cu}\left(\mathrm{CH}_{3} \mathrm{COO}\right)_{2} \quad \mathrm{FeCl}_{2} .2 \mathrm{H}_{2} \mathrm{O}$}

Concentration(M)

$\mathrm{pH}$ 0.05

12

Immersion time (seconds) 35

Rinsing time (seconds) 35

0.05

35

35

$\mathbf{S}_{2} \mathbf{H}_{5} \mathbf{N S}$
0.05
12
35

\section{Results and discussion:}

\subsection{Structural Characterisation:}

The structural characterizations of $(\mathrm{PbS})_{x}(\mathrm{Fe})_{(1-x)}$ and $(\mathrm{CuS})_{x}(\mathrm{Fe})_{(1-x)}$ thin films were carried out using X-ray diffraction (XRD) technique. The peaks of XRD patterns have been assigned from the X-ray diffraction files ref. numbers : INEL/EZEMA/18-162115 and INEL/EZEMA/18-171343 respectively. Using the PbSFe as case study, detailed analyses are given in Tables 1 and 2 below. The crystallite size of the deposited material was calculated by using Debye- Scherer's formula (equation 2)

$\mathrm{D}=\mathrm{K} \lambda / \mathrm{B} \cos \theta$,

where $\mathrm{D}$ is the average crystallite size, $k$ is the particle shape factor that varies with the method of taking the breadth and shape of crystallites , $\lambda$ is the X-ray wavelength used $(0.1542 \mathrm{~nm}), \beta$ is the angular line width of halfmaximum intensity (FWHM) of the diffraction peak, and $\theta$ is the Bragg's angle in degrees. See tables 1 and 2 below.

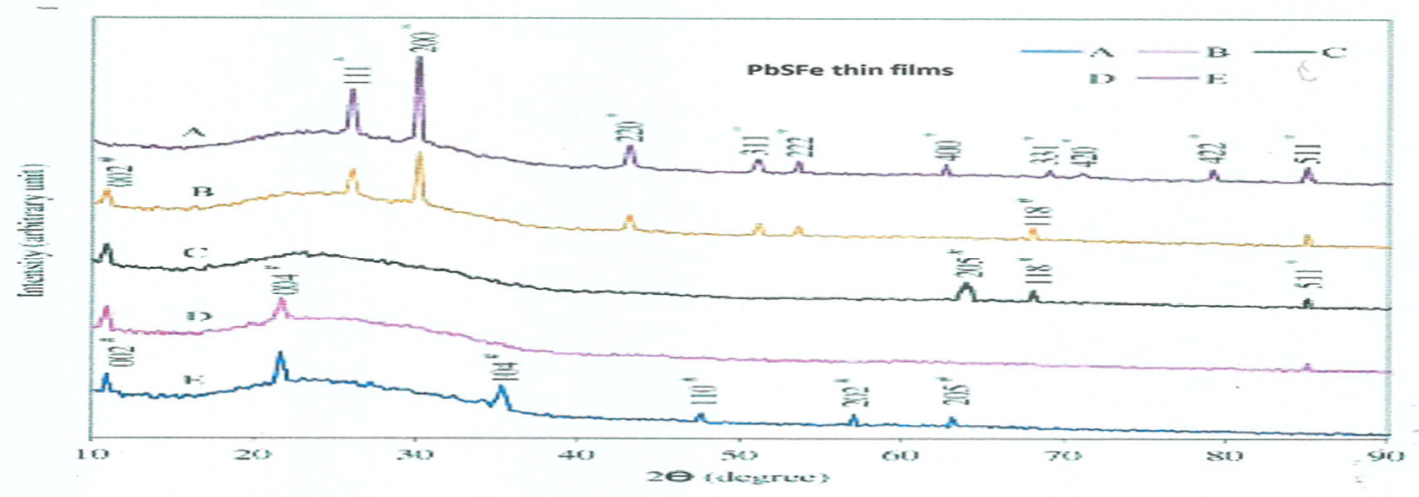

Figure 1. XRD of $(\mathrm{PbS})_{x}(\mathrm{Fe})_{(1-x)}$ composite thin films: $(\mathrm{A}) \mathrm{PbS},(\mathrm{B})(\mathrm{PbS})_{0.80}(\mathrm{Fe})_{0.20},(\mathrm{C})(\mathrm{PbS})_{0.5}(\mathrm{Fe})_{0.5},(\mathrm{D})$ $(\mathrm{PbS})_{0.20}(\mathrm{Fe})_{0.80}$ and $(\mathrm{E})(\mathrm{PbS})_{0.10}(\mathrm{Fe})_{0.90}$. 


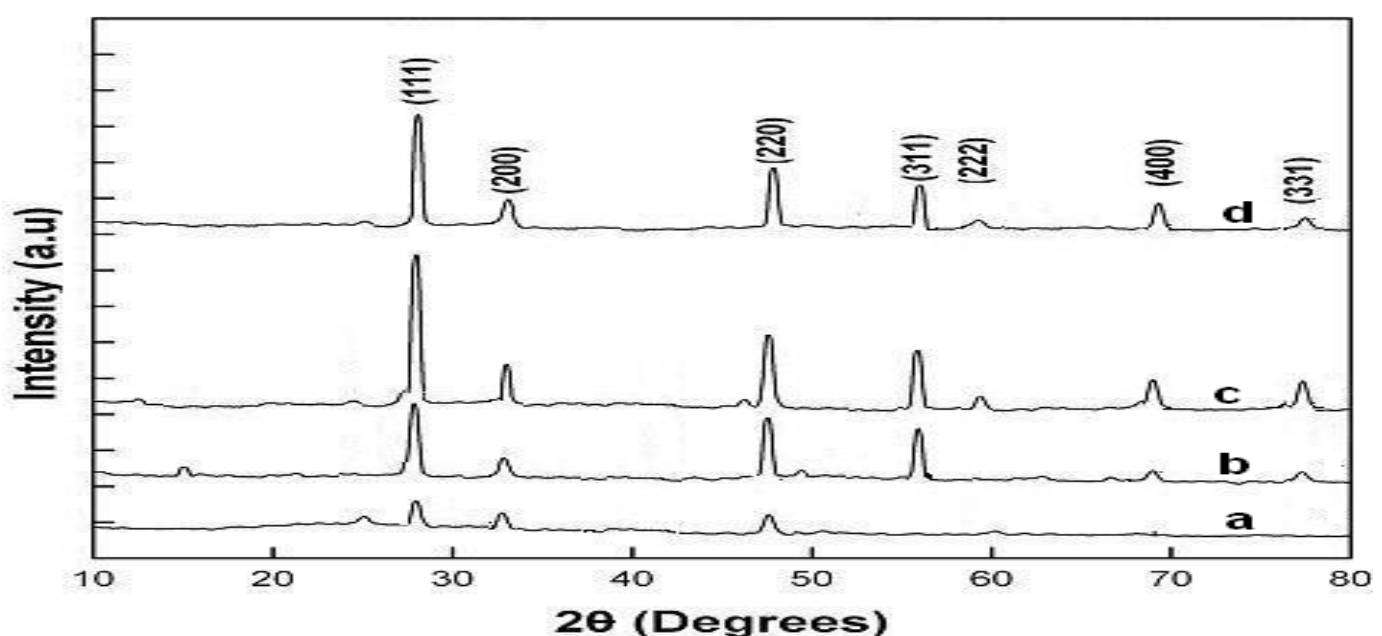

Figure 2 :XRD of $(\mathrm{CuS})_{x}(\mathrm{Fe})_{(1-x)}$ composite thin films: (a) $(\mathrm{CuS})_{0.50}(\mathrm{Fe})_{0.50}(\mathrm{~b})(\mathrm{CuS})_{0.20}(\mathrm{Fe})_{0.80,}(\mathrm{c})(\mathrm{CuS})_{0.1}(\mathrm{Fe})_{0.9}$, (D) $\mathrm{CuS}$

Table 1. Thickness, grain size, strain and dislocation density of $(\mathrm{PbS})_{x}(\mathrm{Fe})_{(1-x)}$ thin films.

$\begin{array}{lllll}\begin{array}{l}\text { Film } \\ \text { composition }\end{array} & \begin{array}{l}\text { Thickness } \\ (\mathbf{n m})\end{array} & \begin{array}{l}\text { Grain } \\ \text { Size } \\ (\mathbf{n m})\end{array} & \begin{array}{l}\text { Dislocation } \\ \text { density } \\ \left(\delta \times 1^{10}\right) \\ \text { lines } / \mathbf{c m}^{2}\end{array} & \begin{array}{l}\text { Strain } \\ \left(\varepsilon \times 1^{-4}\right)\end{array} \\ \end{array}$

\begin{tabular}{llllll}
$\mathrm{A}$ & $\mathrm{PbS}$ & 375 & 34 & 10.91 & 10.17 \\
$\mathrm{~B}$ & $(\mathrm{PbS})_{0.80}(\mathrm{Fe})_{0.20}$ & 301 & 26 & 14.26 & 14.30 \\
$\mathrm{C}$ & $(\mathrm{PbS})_{0.5}(\mathrm{Fe})_{0.5}$ & 290 & 25 & 15.99 & 14.77 \\
$\mathrm{D}$ & $(\mathrm{PbS})_{0.20}(\mathrm{Fe})_{0.80}$ & 285 & 18 & 16.87 & 14.90 \\
$\mathrm{E}$ & $(\mathrm{PbS})_{0.10}(\mathrm{Fe})_{0.90}$ & 280 & 16 & 32.47 & 21.03 \\
\hline
\end{tabular}

Table 2. Thickness, grain size, strain and dislocation density of $(\mathrm{CuS})_{x}(\mathrm{Fe})_{(1-x)}$ thin films.

\begin{tabular}{lllll}
$\begin{array}{l}\text { Film } \\
\text { composition }\end{array}$ & $\begin{array}{l}\text { Thickness } \\
(\mathbf{n m})\end{array}$ & $\begin{array}{l}\text { Grain } \\
\text { Size } \\
(\mathbf{n m})\end{array}$ & $\begin{array}{l}\text { Dislocation } \\
\text { density } \\
\left(\boldsymbol{\delta} \times \mathbf{1 0}^{\mathbf{1 0}}\right)\end{array}$ & $\begin{array}{l}\text { Strain } \\
\left(\boldsymbol{\varepsilon} \times \mathbf{1 0}^{-4}\right)\end{array}$ \\
$\begin{array}{l}\text { lines } / \mathbf{c m}^{\mathbf{2}} \\
\text { CuS }\end{array}$ & 386 & 35 & 10.47 & 10.17 \\
$(\mathrm{CuS})_{0.80}(\mathrm{Fe})_{0.20}$ & 300 & 33 & 14.66 & 11.30 \\
$(\mathrm{CuS})_{0.5}(\mathrm{Fe})_{0.5}$ & 298 & 30 & 15.92 & 13.77 \\
$(\mathrm{CuS})_{0.20}(\mathrm{Fe})_{0.80}$ & 287 & 19 & 17.57 & 14.99 \\
$(\mathrm{CuS})_{0.10}(\mathrm{Fe})_{0.90}$ & 273 & 17 & 32.47 & 21.34 \\
\hline
\end{tabular}

\subsection{Morphological Studies}

The morphological characterisation of $\mathrm{CuS}, \mathrm{CuSFe}, \mathrm{PbS}$ and $\mathrm{PbSFe}$ thin films were done using the scanning electron microscopy analysis(SEM) and Energy Dispersive spectrometry analysis .

3.2.1 Scanning electron microscopy(SEM) analysis

The SEM Micrographs of the doped and undoped $\mathrm{PbS}$ and $\mathrm{CuS}$ thin films are show in Figures 3 and 4 below: 


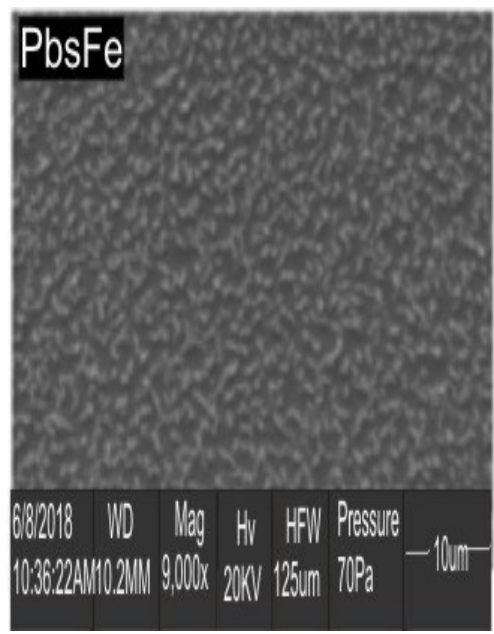

(A)

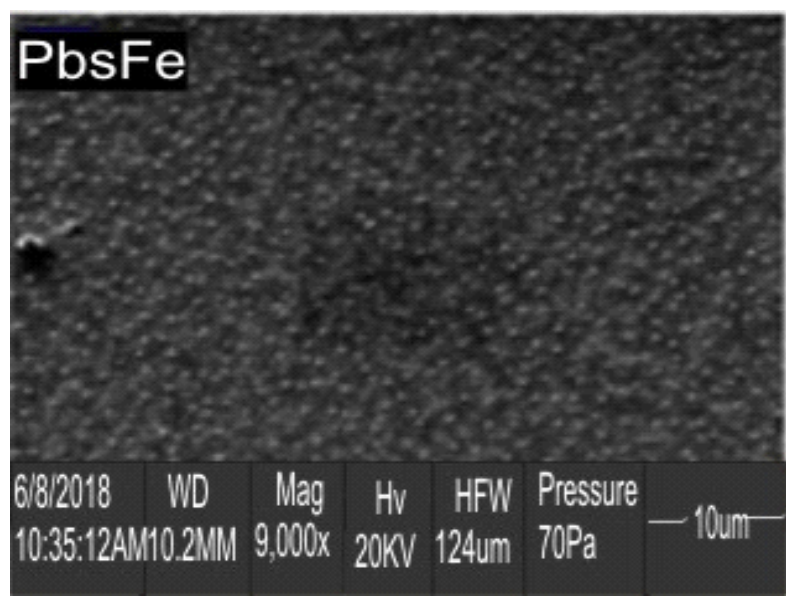

(B)

Figure 3. SEM images of $(\mathrm{PbS})_{x}(\mathrm{Fe})_{(1-x)}$ composite thin films: $\left.(\mathrm{A}) \mathrm{PbS}\right)_{0.20}(\mathrm{Fe})_{0.80}$, at $10 \mu \mathrm{m}(\mathrm{HFW}=125 \mu \mathrm{m})(\mathrm{G})$ $(\mathrm{PbS})_{0.8}(\mathrm{Fe})_{0.2}$. at $10 \mu \mathrm{m}(\mathrm{HFW}=124 \mu \mathrm{m})$ SEM of doped $\mathrm{CuS}$ thin film SILAR (deposited at 90cycles) is shown below in Figure 6 below.
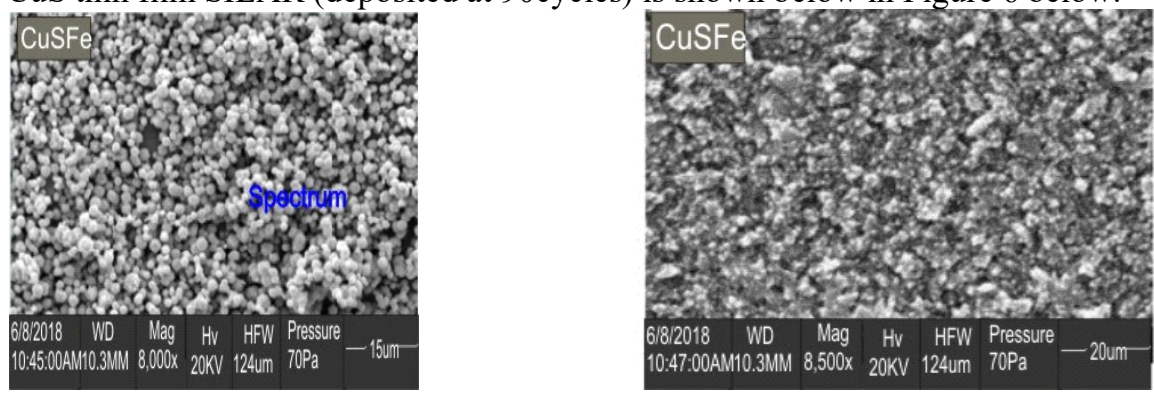

Figure 4. SEM Micrograph of CuSFe (A) micrograph at $15 \mu \mathrm{m}$ (B) micrograph at $20 \mu \mathrm{m}$

3.2.2 Energy Dispersive Spectrometry (EDS) Analysis : These are show in Figures 7 and 8 below.

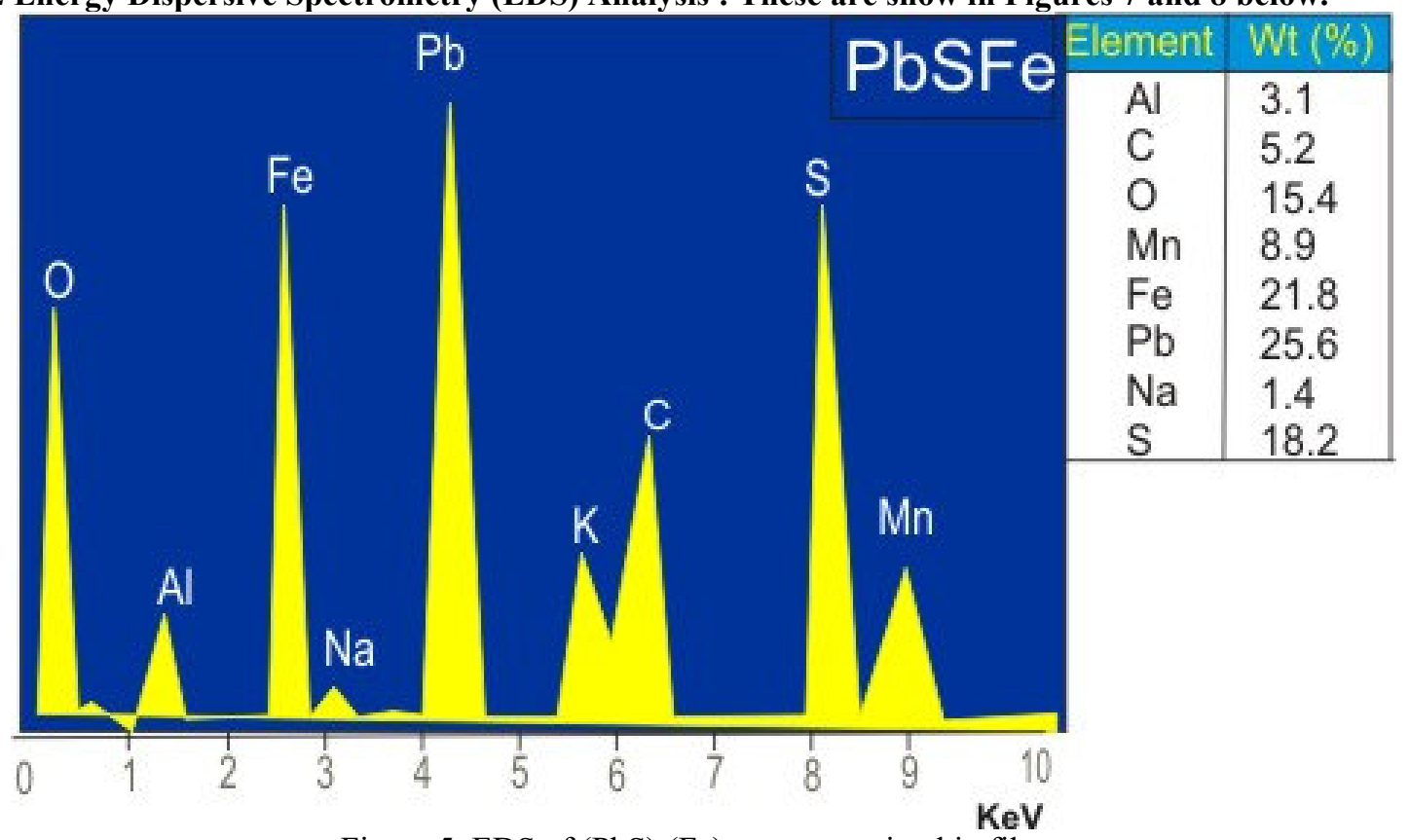

Figure 5. EDS of $(\mathrm{PbS})_{x}(\mathrm{Fe})_{(1-x)}$ composite thin films: 


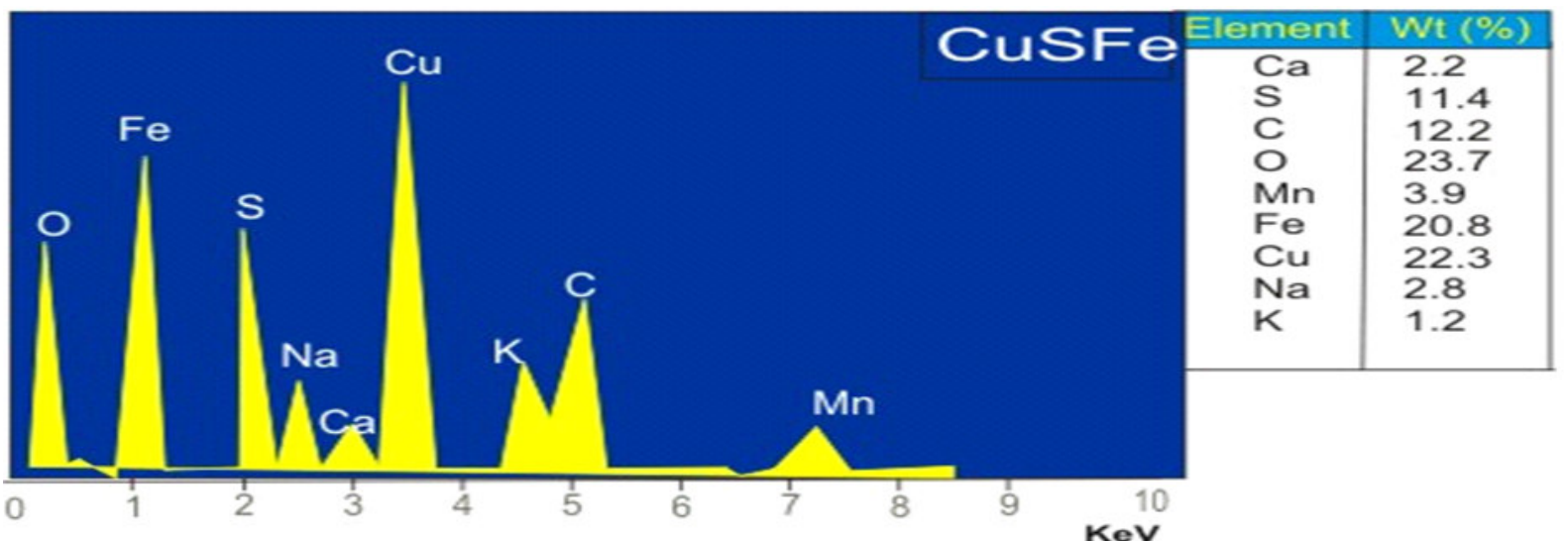

Figure 6. EDS of $(\mathrm{CuS})_{x}(\mathrm{Fe})_{(1-x)}$ composite thin films:

\subsection{Optical characteristics}

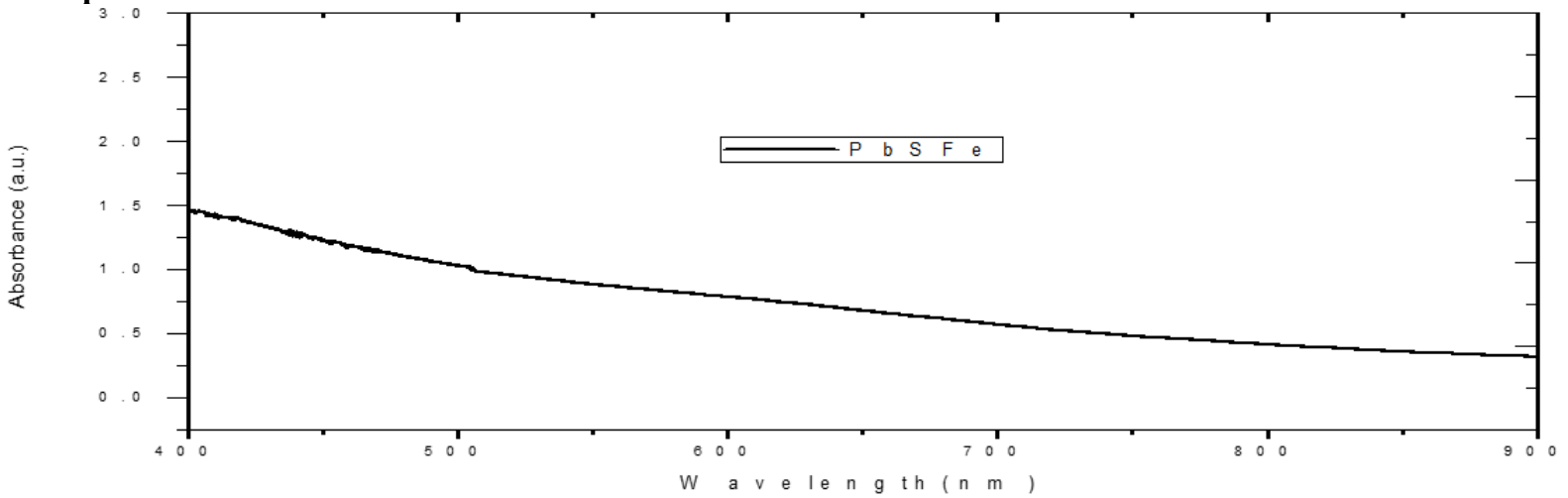

Fig 7: Plots of absorbance against wavelength for PbSFe thin film

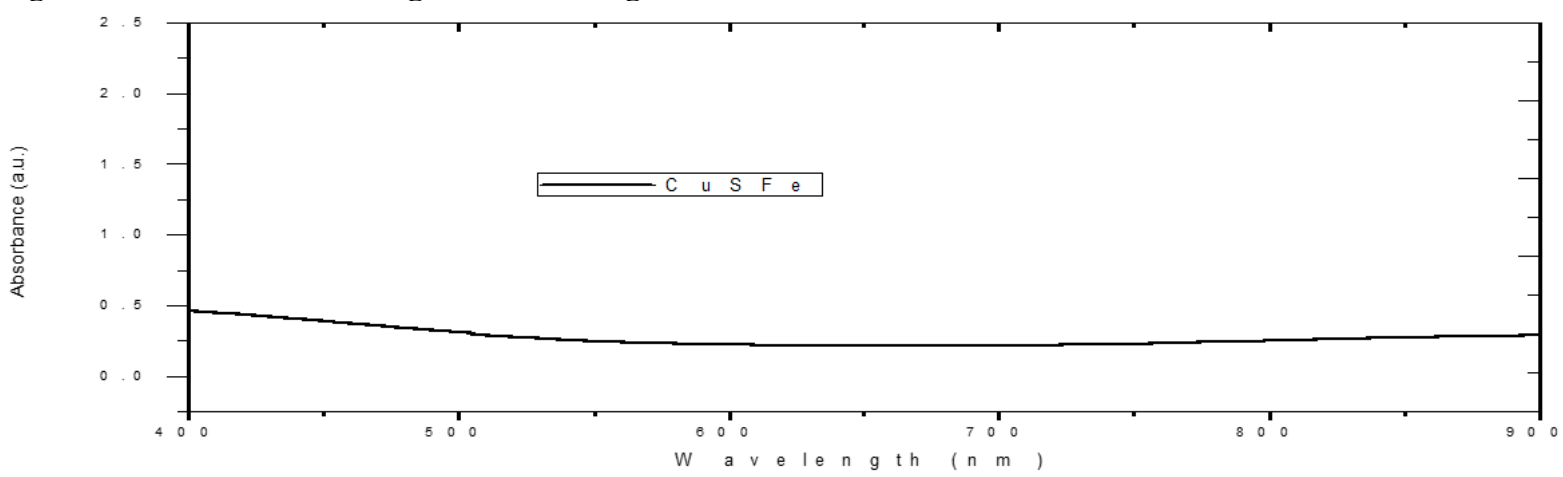

Fig 8: Plots of absorbance against wavelength for $\mathrm{CuSFe}$ thin film

Fig.7 shows the plots of absorbance against wavelength of PbSFe thin films while Figure 9 depicts the plots of transmittance against wavelength. Figure 8 shows the plot of absorbance against wavelength of CuSFe thin films while Figure 10 depicts the plots of transmittance against wavelength for CuSFe thin films. The absorbance spectra of PbSFe thin films (Fig.7) vary in a manner, decreasing continuously from 1.40 (a.u) at 400nm to about 0.50 at $900 \mathrm{~nm}$. This range of absorbance is in agreement with the reports of Uhugebu (2007) for FePbS thin films, Agbo and Nnabuchi (2011) for $\mathrm{TiO}_{2} / \mathrm{PbO}$ thin films, and Onah,Ugwu and Ekpe (2015) for $\mathrm{TiO}_{2} / \mathrm{CuO}$ thin films. The absorbance spectra of CuSFe thin films (Fig.8) shows that the thin films decreased with wavelength within $400-500 \mathrm{~nm}$ and then remained fairly constant within the wavelength range $550-700 \mathrm{~nm}$. Thereafter, it increased within the wavelength range $750-900 \mathrm{~nm}$. The maximum absorbance is about 0.5 (a.u.) at $400 \mathrm{~nm}$. This value of absorbance is below the maximum of 1.50 (a.u) by Uhuegbu (2007) for $\mathrm{FeCuS}_{2}$ thin films. The high absorbance displayed by PbSFe films may be used as spectrally selective coating for solar thermal applications. Solar collectors for heating fluids require increasing the reception area of the solar radiation, and/or to increase the absorbance of the surface coating in order to improve thermal efficiency (Oliva, Maldonado, Diaz and Montolvo, 2013). These findings are in agreement with the report of Augustine and Nnabuchi (2018) for $\mathrm{CuO} / \mathrm{PbS}$ thin films. SUMMARY:X-ray diffraction patterns of $\mathrm{CuS}-\mathrm{Fe}$ and $(\mathrm{PbS})_{x}(\mathrm{Fe})_{1-x}$ composite films were shown in Fig.1 and 2 above. The peaks of XRD patterns have been assigned from the x-ray diffraction files ref. numbers : 
INEL/EZEMA/18-162115 and INEL/EZEMA/18-171343 respectively.

Lead sulphide thin film has ten diffraction peaks (111)(200 (220) (311) (222)(400) (331)(420)(422)(511), which corresponds to $2 \theta$ angles ranging from10.098-85.846. The XRD of doped $\mathrm{PbS}$ and $\mathrm{CuS}$ annealed at about $650 \mathrm{~K}$ has been included. These had thirteen and seven peaks ranging from angles $2 \theta$ ranging from 10.429-85.9645 and 18.012-80.012 respectively. The $\left(\begin{array}{lll}0 & 0 & 2\end{array}\right)$ and $\left(\begin{array}{lll}0 & 0 & 4\end{array}\right)$ orientations due to hexagonal lattice are prominent in $\mathrm{CuSFe}$ and $\left(\begin{array}{lll}1 & 1 & 1\end{array}\right)$ and $\left(\begin{array}{lll}2 & 0 & 0\end{array}\right)$ orientations due to cubic lattice are distinct in pure $\mathrm{PbS}$ and $\mathrm{CuS}$ thin films. The $\mathrm{PbSFe}$ thin films annealed at temperature less than $500 \mathrm{~K}$ were crystals that was cubic and face-centred. However, at $x=0.5$ i.e. for $(\mathrm{PbS})_{0.5}(\mathrm{Fe})_{0.5}$, and $(\mathrm{CuS})_{0.5}(\mathrm{Fe})_{0.5} \quad$ strong orientations disappear showing the non-formation of crystals due to the sp-d orientation. The crystallite sizes of the deposited materials were calculated using DebyeScherer's formula.

Thickness for $\mathrm{PbS},(\mathrm{PbS})_{0.8}(\mathrm{Fe})_{0.2},(\mathrm{PbS})_{0.5}(\mathrm{Fe})_{0.5},(\mathrm{PbS})_{0.2}(\mathrm{Fe})_{0.8},(\mathrm{PbS})_{0.1}(\mathrm{Fe})_{0.9}$ were $375 \mathrm{~nm}, 301 \mathrm{~nm}, 290 \mathrm{~nm}$, $285 \mathrm{~nm}$ and $280 \mathrm{~nm}$ while their grain sizes were $34,26,25,18,16$. Their dislocation density $(\partial)$ calculated were $10.91,14.26,15.99,16.87$ and 32.47 respectively. The strain were calculated as 10.77, 14.30,14.77,14.90 and 21.03 respectively while thickness for $\mathrm{CuS},(\mathrm{CuS})_{0.8}(\mathrm{Fe})_{0.2},(\mathrm{CuS})_{0.5}(\mathrm{Fe})_{0.5},(\mathrm{CuS})_{0.2}(\mathrm{Fe})_{0.8,}(\mathrm{CuS})_{0.1}(\mathrm{Fe})_{0.9}$, , were $386,300,298,287,273$ while their grain sizes were $35,33,30,27,19,17$. The variation in the strain and dislocation density may influence the properties on the nanostructures. The compositional analysis showed that the iron content of the SILAR synthesized PbSFe thin films was $21 \mathrm{wt} \%$ and CuSFe thin films was $20.8 \mathrm{wt} \%$.

From literature, the lead Sulphide thin films have been reported as having thermal stability as observed in this study. The samples(doped and undoped) were annealed between temperatures of $293 \mathrm{~K}$ and $493 \mathrm{~K}$ and from the XRD, the intensity ratio some diffractions changed but no additional peaks were observed up to $475 \mathrm{~K}$; This showed that the $\mathrm{PbS}$ nanofilm was not oxidized. The change in the diffraction reflection intensities was attributed to the fact that the phase transition to cubic structure takes place in the PbS film at 375K (Qadri et al. 2003).

The presence of oxygen atoms as shown by the EDS studies showed that the proportion ofiron to lead sulphide and iron to copper sulphide were not in equal proportion and also oxidation must have taken place because of their large surface area(Qadri et al. 2003). Based on this finding, the lead sulphide thin films (doped and undoped ) can be used in devices as fire alarm sensors, flame sensors and heat source detection systems.

\subsection{Conclusions}

A simple, cheap and convenient SILAR method was be employed to deposit good quality $\mathrm{CuSFe}$ and $(\mathrm{PbS})_{x}(\mathrm{Fe})_{1-x}$ composite thin films. The deposited films were uniform and adherent to the substrate. Their structural and morphological properties of those composite thin films were studied.The EDS Studies showed that in $(\mathrm{PbS})_{x}(\mathrm{Fe})_{1-x}$ composite thin films, the composition of iron was $21.8 \mathrm{wt} \%$ while in $(\mathrm{CuS})_{x}(\mathrm{Fe})_{1-x}$ composite thin films, iron composition was $20.8 \mathrm{wt} \%$.. The XRD and morphological studies revealed that $\mathrm{CuSFe}$ and $\mathrm{PbS}_{x}(\mathrm{Fe})_{(1-x)}$ thin films were nanocrystalline in nature depending on film composition. The average crystallite size was found to vary for the CuSFe thin films between 35 and $17 \mathrm{~nm}$ and for PbSFe thin films 34 and16 depending on film composition. The variation in thickness, strain and dislocation densities were also composition dependent. Similar observation has been reported by Wang et al. The samples annealed at different temperatures (383K-500K) never showed any prominent peaks structurally and morphologically as confirmed by studies done by He et al., From literature, considerable changes can be seen for temperatures up to $700{ }^{\circ} \mathrm{K}$ (Mote, 2012). The high absorbance displayed by $\mathrm{PbSFe}$ films may be used as spectrally selective coating for solar thermal applications. Solar collectors for heating fluids require increasing the reception area of the solar radiation, and/or to increase the absorbance of the surface coating in order to improve thermal efficiency. The relatively high transmittance of $\mathrm{PbSFe}$ and $\mathrm{CuSFe}$ thin films in the infrared region suggest that they may be used for coating the walls and roofs of poultry houses to facilitate the transmission of infrared radiation in order to generate the heat required for warming young chicken. These properties can be well used in solar energy conversion devices and optoelectronics.

\section{ACKNOWLEDGMENT}

The authors are grateful to Nanoscience Research Group, University of Nigeria Nsukka

\section{REFERENCES}

Adegbenro, O. (2011). Challenges and Prospect of Energy Efficiency and Conservation. Journal of Energy Policy, Research and Development, 1(1), 104-110.

Akujor, C (1988): Energy Technology, Summer Educational Publishers (Nig.) Limited, Onitsha..1,4-6

Bala, E.J., Ojosu, J.O., and Umar, I.H., Government Policies and Programmes on the Development of Solar PV Sub-sector in Nigeria.(2008) Nigeria Journal of Renewable Energy, 8(1 and 2): 1-6.

Boer, K.W.,(1977), Physica Status Solidi. A40, 435.

Chaudhuri, T. K. and Chatterjes, S. (1992).Ternary Thin Films, Proceedings of the International Conference on Thermoelectronics.New Jersey, N.Y, 11: 40.

Fernandes, P.A., Salome, P.M. and Cunha, A.F. (2010). A study of ternary $\mathrm{Cu}_{2} \mathrm{SnS}_{3}$ and $\mathrm{Cu}_{2} \mathrm{SnS}_{4}$ thin Films 
prepared by sulphurizing stacked metal precursors, Journal of Physics D: Applied Physics, 43, 1-11.

He, Y, Yu, X and Zhao, X. (2007), Materials latter, 61, 3014

Ibrahim, S. G. and Salame, P. H. (2016). Thickness Dependent Physical Properties of lead Sulphide thin Films, Int. J. Chemistry, 6:5-11

Jesuleye, A.O. and Siyanbola, W.O. (2008). Solar Electricity Demand Analysis for Improved Access to Electricity in Nigeria.. Nigeria Journal of Solar Energy. (1): 136-141.

JCPDF Powder Diffraction File search manual - 2003, 89-2073.

Mote, V., Y. Purushotham, Y., and Dole, B.(2012), The morphological, optical and electrical properties of nanocrystalline PbS thin films,, J. Theor. Appl. Phys. 6, 17.

Nicolau, Y. F, Dupuy M, Brunnel, M (1990): Journal of Electrochemical society, 137, 2915.

Oji ,J. O, Nascu, C., Pop, I.and lonescu, V. (2012). Utilisation of Solar Energy for Power Generation in Nigeria. International Journal of Energy Engineering , 2(2):54-5

Liang,W and Whangbo, M.H(1993): Solid State Communications. 85 (1993) 405

Nwoke, O. O., Okonkwo, W. I. and Oparaku, O. U. (2008). Solar Energy Use in Nigeria: constraints and Possible Solutions. Nigeria Journal of Solar Energy, 19(1), 90-93.

Nair, M T.S, Alvarrez-Garcia,G., Estrada-Gasva C.A. and Nair, P.K(1993); Journal of Electrochemical Society. $140,212$.

Nair, P.K., Garcia, V.M., Fernandez, A. M. Ruiz H.S and Nair, M.T.S (1991), Journal of Physics D. $24,441$.

Han, Z.H. Li, Y.P., Zhao, H.Q., Yu, S.H., Yin, Y.L., and Qian, Y.T(2000), Materials Letters. 44, 366.

Okafor, E.C.N. and Joel-Uzuegbu, C.K.A.(2010). Challenges to Development of Renewable Energy for Electric Power Sector in Nigeria. International Journal of Academic Research. 2(2): 211-216.

Qadri, S. B. , Singh, A. and Yousuf, M.(2003): Structural stability of PbS Films as a function of temperature, Thin Solid films, 431(432),506-510

Wang, S.Y, Wang, W,Lu,Z.H(2003):Material Science and Engineering, B10,3184

Okonkwo, W. I. Passive Passive Solar Heating, for Poultry Chick Brooding in Nigeria. A Paper presented at the International Workshop on Renewable Energy for Sustainable Development in Africa, $2^{\text {nd }}$ May, 2007

Olivia, A. I., Maldonado, R. D., Diaz, E. A. and Montolvo, A. I. (2013). A high absorbance material for solar collector's applications, Materials Science and Engineering, 45, 1-4.

Onah, D. U., Ugwu, E.I. and Ekpe, J. E. (2015). Optical Properties of Nanocrystalline $\mathrm{TiO}_{2} / \mathrm{CuO}_{\text {Core-Shell Thin }}$ Films by Thermal Annealing, American Journal of Nano Research and Applications, 3(3), 62-65.

Sambo, A.S (2008). The Role of Energy in achieving Millenium Development Goals (MDG): Keynote Address of the National Engineering Conference (NETEC), Ahmadu Bello University, Zaria, 1st April, 2008.

Smith, G. B., Ignatiev, A. and Zajac, G.(1980).Copper sulphide nanocrystalline thin films at room temperature, Thin Solid films, 514, 132-137.

Whitefield, D. (2000). Solar Dryer System and the Internet Important Resources to Improve food preparation. A Paper presented at International Conference on Solar Cooking, Kimberly, South Africa, and 24th June, 2000.

Valenzuela, J., J'auregui, R., Ram'irez-Bon, A., Mendoza-Galva'n, M. and Sotelo-Lerma, A. (2003). Optical properties of $\mathrm{PbS}$ thin films chemically deposited at different temperatures. Thin Solid Films, 1441: $104-110$.

Yucel, E., Yucel, Y., Beleli, B.(2015). Process optimization of deposition conditions of PbS Appl. Phys. Lett., 56, 51-53. 